\title{
Researchfocus \\ Privatisation, pluralisation and the globalisation of policing
}

\author{
Philip Stenning \& Clifford Shearing
}

\section{INTRODUCTION}

Throughout history, 'policing' has essentially been about maintaining and enforcing'order' (the way things 'should be') or, as it was referred to in earlier days, 'peace' (hence police came to be referred to as 'peace officers'). Beginning in the 19th Century, however, the provision of 'policing' in what are now Commonwealth countries has undergone some sea changes.

The best known of these was the introduction in England of the 'new police' (modern public police forces) in the early 19th Century. This saw a new state institution ('the police') take over primary responsibility for policing and law enforcement from the citizenry, private complainants and prosecutors. This new institution has been regarded as the dominant provider of policing services in all Commonwealth jurisdictions ever since.

During the last quarter of the 20th Century, another sea change (which Bayley \& Shearing (1996) have argued was just as significant as the earlier one in the 19th Century) began when the provision of a great deal of policing began to be privatized, pluralized and globalized.

As such we now experience a contested field of policing provision in which a wide variety of different state and non-state organisations and actors are competing for dominance in the provision of policing and security services all over the world.

In this article, we describe in more detail the main features of this modern transformation in policing and security provision, discuss some of its most important implications, and consider how the public police might best respond to it and to the challenges that it poses. Of course, we don't have all the answers - no-one does - but we can lay out some of the key questions about it that various commentators and critics have suggested need to be addressed.

\section{What do the police do?}

Since 'policing' is no longer just what 'the (public) police' do, we are challenged to redefine what we mean by 'policing'. The following definition has been offered by Crawford and his colleagues (Crawford, 2005, p. 4):

"For our purposes 'policing' is defined as intentional action involving the conscious exercise of power or authority (by an individual or organisation) that is directed towards rule enforcement, the promotion of order or assurances of safety."

There are several advantages to this as a definition of 'policing' in the modern pluralized, globalized policing environment:

1. Neither the state nor the public police are specifically mentioned in it;

2. None of the words 'crime', 'law' or 'criminal justice' appear in it;

3. The definition doesn't suggest that policing is necessarily something that is only undertaken within a specified geographical territory;

4. It refers to 'power' as well as 'authority' as a basis for policing;

5. It notes that policing does not necessarily have to be done by an 'individual'; and

6. Despite these previous five features, the definition easily covers what the public police do.

\section{Understanding the transformation of the landscape}

The transformation that has been occurring has involved the diffusion and diversification of policing and security provision within nation states, above them, below them, and beyond them. We consider each of these in turn. 


\section{Diffusion and diversification within nation states}

The original mandate of the 'new police' set out in England in the early 19th Century was very broad, even though in their original Instructions to the London Metropolitan Police in 1829, the new Commissioners identified the prevention of crime as the police's core mandate.

Throughout the 19th and early 20th Centuries, however, many of the police's functions that were not directly crime-related (e.g. regulation of markets, licensing taxicabs, etc.) were gradually assumed by other new specialised government bodies. But with the introduction of new technologies (e.g. the automobile, the computer), they also assumed new responsibilities that they had not had before. Despite this, their policing was increasingly presented (by them) as involving crime control and law enforcement (i.e. the maintenance of state-defined order through enforcement of state law).

Even during this period, various kinds of specialised policing functions were assigned to institutions other than the "regular police" - e.g. border control (Coast Guard, Ports, Docks and Harbour Police, Revenue \& Customs, and Immigration Service, etc.), the policing of railways (Railway Police) etc. Responsibility for national security policing was given to separate agencies (e.g. the Australian Security Intelligence Organisation (ASIO) and the Australian Secret Intelligence Service (ASIS). During the second half of the 20th Century, this trend increased significantly (e.g. the establishment of the National Crime Authority in 1984, with a special mandate to police organised crime in Australia, and the establishment of various state bodies, such as Queensland's Crime and Corruption Commission, with a specialised mandate to police corruption and police deviance). For a full list of these specialised agencies in Australia, see Prenzler \& Sarre, 2006: 180-185.

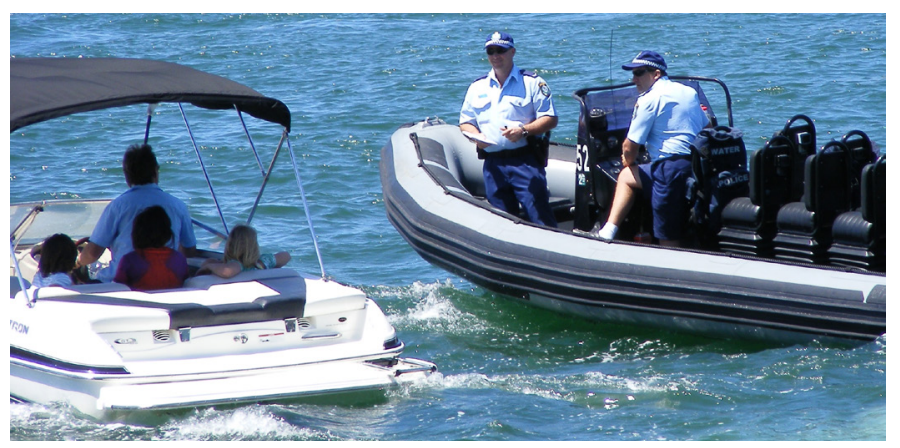

Some governments have established 'second tier' police personnel who do not have the authority of regular sworn police officers, but are employed by police services to do policing work in support of their sworn colleagues (e.g. Police Community Support Officers (PCSO's) in the UK - see www.parliament.uk/briefing- papers/sn02718.pdf for a national evaluation of this scheme). These PCSO's have been claimed to be an important element in the delivery of "reassurance policing" (Millie \& Herrington, 2006) and as such contribute to the broader crime control work of the sworn police.

After the terrorist attacks in the U.S. in 2001 (9/11), some countries established substantial 'umbrella' policing organisations with a special mandate to co-ordinate anti-terrorism policing. The Department of Homeland Security in the U.S. is the most well-known of these.

So even policing within and by the state has been significantly "pluralized" during the late 20th and early 21 st Centuries. This has led to greater variety in the governance and accountability of state-sponsored policing providers, since many of these specialised agencies have their own governing bodies which are not part of the governance structure for the 'regular' public police.

Almost all of these new state-sponsored policing providers, however, share a similar orientation (crime control through law enforcement) to that of the "regular police", although their approach (prevention vs. punishment; proactive vs. reactive, etc.) varies somewhat from one agency to another. Security services such as ASIO and ASIS (responsible for national security) represent a notable exception, and similarly by the Security Service Act, 1996 the function of acting "in support of police forces and other law enforcement agencies in the prevention and detection of serious crime" was added to the mandate of the U.K.'s Security Service.

\section{Diffusion and diversification above nation states}

'Globalisation' and 'internationalisation' have been prominent developments in the late 20th and early 21st Century. 'Globalisation' refers to the expansion of enterprises (especially business enterprises) so that they have an increasingly global reach (think of McDonald's, or Starbucks, or Shell Oil, or Goldman Sachs, Merrill Lynch, etc.).

\section{...globalisation and internationalisation are impacting policing, requiring not only the establishment of international and transnational policing organisations, but also much greater co-operation between national policing organisations.}

'Internationalisation' refers to the process whereby problems and activities become the subject of 
international or 'supranational' (i.e. above the state), rather than just national, initiatives and co-operation (e.g. via such international organisations as the U.N., the G20, ASEAN, the European Union, etc.).

Between them, globalisation and internationalisation are impacting policing, requiring not only the establishment of international and transnational policing organisations, but also much greater cooperation between national policing organisations. These developments have been going on for several decades, but have dramatically increased in recent years.

Since the 1920's, organisations have been established to foster and facilitate international and transnational policing. The two most well-known of such organisations are Interpol (established in 1923) and (since the establishment of the European Union (formerly the European Common Market)) Europol.

Each of these organisations was established through international agreements that provide for co-operation between state-based police organisations to facilitate effective policing of all kinds of international and transnational crime (trafficking and smuggling of drugs, guns, women, children, endangered species, etc.; piracy, internet pornography and other cybercrime; money laundering; terrorism; antiquities and art theft; and counterfeiting. The list grows and grows). With the establishment of the International Criminal Court under the Treaty of Rome (1998), it can be expected that international policing of genocide and other "crimes against humanity" will also increase in the future.

\section{International and transnational policing is not, however, the exclusive preserve of state- supported international organisations.}

Throughout the G8 nations, other international policing structures and regimes have also been established (e.g. the Egmont Group of Financial Intelligence Units, established to police international money-laundering and funding of international terrorist organisations and activities, with concomitant gains across nations). In addition, through organisations such as the United Nations, NATO, the European Union, etc., international peacekeeping and police capacity building missions have increasingly been mounted (in post-conflict states and states "in transition" from non-democratic regimes), to which state-based police organisations contribute.

Again, most of these organisations share the same general orientation (crime control through law enforcement) as that of their state-based counterparts/ participants. International and transnational policing is not, however, the exclusive preserve of state-supported international organisations. Many private (non-state) policing organisations also function in this arena. These are better thought of as transnational, rather than international, policing organisations, because they are not sponsored by nation states, but by nonstate sponsors who are usually, but not exclusively, commercial corporations. They are referred to as 'transnational' because their operations cross national borders. They are considered further below.

\section{Diffusion and diversification below nation states}

With the introduction of "neo-liberal" ideas of governance during the late 1980's and 1990's, there has been a growing trend toward the "devolution" or "downloading" by the state of policing functions that were previously the responsibility of state-sponsored policing providers, to individuals, groups and "communities".

Neo-liberalism has been defined as:

"An approach to economics and social studies in which control of economic factors is shifted from the public sector to the private sector. Drawing upon principles of neoclassical economics, neoliberalism suggests that governments reduce deficit spending, limit subsidies, reform tax law to broaden the tax base, remove fixed exchange rates, open up markets to trade by limiting protectionism, privatize state-run businesses, allow private property and back deregulation."

Source: Link

A trend referred to by neo-liberal scholars by the rather ugly word, "responsibilisation". "Community policing" is, of course, in its intended meaning (but not usually in its reality), a product of this kind of thinking, with the intention being that through community policing communities can start to take ownership over identifying and solving their own crime and disorder problems.

The U.K. has seen the recent advocacy of "double devolution" - devolution of responsibility from central government to local government, and thence from local government to "communities" - an idea which has been seized upon by the current government there as the basis of its promotion of "The Big Society" (The Economist, 2013). From a policing point of view, the idea is that individuals and "community groups" will be increasingly expected to assume responsibility for dealing with crime and disorder within their communities. In pursuance of this goal, locally elected 'Police and Crime Commissioners' were recently 
introduced to replace 'Police Authorities' which were responsible for governing local police services.

Early emanations of this trend were programs like Neighbourhood Watch, Citizen Patrols, CB Radio Patrols, Taxis on Patrol, "Ambassador" programs, etc. which involve citizens and volunteers, usually with the endorsement and support of (and in support of) the "regular police". The Special Constabulary (citizens sworn in as Special Constables, with limited police powers, on a temporary or part-time basis) has historically been the more formal manifestation of such a trend. (The early U.S. equivalent was the Sherriff's Posse.)

In the 1990's and early 21st Century many countries introduced new, 'second level' policing provision at the local level (e.g. Neighbourhood Wardens in the UK (Crawford, 2006); the Stadswachten in the Netherlands (Hofstra, 1995); and Wellington (N.Z)'s City Safety Officers (Coggan \& Gabites, 2007)), as well as at the national level (e.g. the aforementioned Police Community Support Officers (PCSO's) in the UK). This "below state" policing provision has been referred to by some scholars as "Grey Policing" (Hoogenboom, 1991).

Note that when such programs are developed without the support of the police, or are actively opposed by police, they are usually labelled as forms of "vigilanteism" - which may arguably include the Guardian Angels in New York City; violent gangs in the favelas (poor suburban areas) of some South American countries and in South Africa's Black townships; and unofficial sectarian "militia" groups in Northern Ireland. Whilst arguably focused on crime control, it is easy to conclude that the necklacing and knee-capping activities favoured by these last two groups do not accord with the 'justice' considerations that we tend make when considering the role of police.

\section{Diffusion and diversification beyond (or outside) nation states}

Sometimes referred to as "parallel policing" or "parapolicing" (Rigakos, 2002), but more commonly as simply "private security" or "private policing", this trend beyond nation states includes a huge array of privately (non-state) sponsored policing provision.

\section{...the last four decades of the 20th Century saw a massive growth in this [private security/policing] sector}

Although private policing provision has always been with us (through the corporate industrial police forces of the coal and steel industries in the U.S. in the 19th
Century; and investigation agencies such as Pinkertons ${ }^{1}$ , Wackenhut and Wells Fargo), the last four decades of the 20th Century saw a massive growth in this sector, particularly, but by no means exclusively, in North America. Indeed, the 'new' Metropolitan London Police of 1829 was inspired by a private policing experiment with the "Thames River Police", which had been established in 1798 by shipping companies. The private (non-state) policing sector can usefully be divided into the "contract" and "in-house" sectors:

- The "contract security industry" is made up of companies that supply various security and policing services and products to clients on a contractual basis - these are corporations that are in the business of supplying security and policing services for profit.

- The "in-house security sector" consists of security or policing services established within corporations or institutions to service only those corporations' or institutions' security or policing needs. This might include a credit card or insurance company's in-house fraud detection unit, or a retailer's inhouse security service to prevent and respond to shoplifting by customers and embezzlement and "pilferage" by staff.

The private policing sector provides a huge array of security and policing services and products, including, for example:

- Static and mobile guard and patrol services;

- Investigative services (private detectives and forensic accountants);

- Security consulting services;

- Secure cash-carrying services (armoured cars);

- Personal protective services (bodyguards, etc.);

- Alarm manufacturing, installation, servicing and response; and

- Provision of many other kinds of security equipment (including CCTV; protective screens; electronic access and locking systems; voice, retina and photographic recognition systems; safes and vaults; guard dogs; body armour; and weaponry).

Most of the large contract security companies such as Group 4, Securicor, Wackenhut, and Serco, provide a wide range of such services and products, including, in some cases, provision of "private prisons" and detention facilities. The sector may also be thought of as divided into the manned security sector (which is labourintensive and involves the deployment of security personnel) and the security hardware sector (resting on the provision, installation, servicing, monitoring and responding to security equipment).

1. Note that the FBI in the U.S., founded in 1919, was developed from the files and networks of the Pinkerton Detective Agency. 


\section{The line between public and private policing has become increasingly blurred.}

The private sector (both contract and in-house) services local, national (state) and international markets play a key role at all levels of policing provision. Since its sponsors and clients are mostly for-profit corporations it is organised mainly to service their corporate security and policing needs. National and local state governments, however, are increasingly frequent clients of the contract security industry, since it tends to be a less costly provider of certain policing services than the public police, including the guarding of government buildings, and protecting government property. Private security contractors also have states as their clients through their transnational operations (e.g. the former Blackwater (which changed its name to $\mathrm{Xe}$, and then again to Academi (Scahill, 2011)) in Iraq and Afghanistan). International NGO's such as the Red Cross and Médecins Sans Frontières also contract with private security companies to protect their staff and facilities.

The line between public and private policing has become increasingly blurred. Municipal governments in many countries now contract with private contract security providers for the provision of policing services including patrolling city parks or public housing estates (see e.g. Jones \& Newburn, 1998), which was previously thought of as the domain of the public police. This blurring continues further when we consider that private companies - such as jewellery stores and sports stadiums - also sometimes contract the services of off-duty or "special pay duty" public police officers to provide private policing to them.

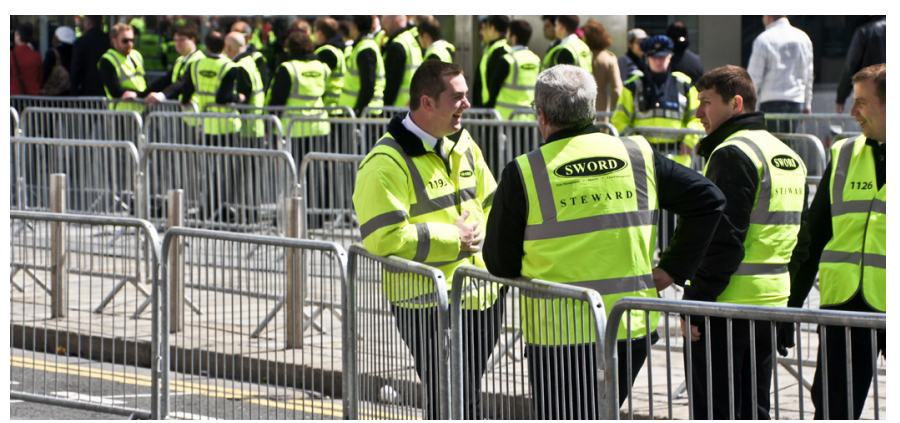

Some very large international organisations successfully "enrol" states to do the policing that they consider necessary for them to conduct their business/operations. FIFA (the international football association) provides a good example. Providing policing and security that meets FIFA's requirements is a condition of hosting the Football World Cup, which FIFA sponsors. The same is true of the International Olympic Organisation (IOC). These are examples of states in effect being under contract to non-state international organisations.
The size of the private policing market and its reach into activities traditionally undertaken by public police is signaled by one of the largest private security company in the world, G4S, which now has a "Policing Support Services" division, which provides services to public police forces under contract ${ }^{2}$. Thus it is not only private citizens and corporations that invest in the services of the private police. The public police do so too.

Four important features of the private policing sector are:

- The "order" that they seek to police is typically determined by private sponsors or clients, rather than by the state, and prioritises private interests rather than the broader "public interest"that the state police (are supposed to) reflect in their provision.

- Their policing orientation and practices are not necessarily (and often not much) about crime control and law enforcement, but towards more private, profit-related goals such as loss prevention, risk management, personal security (e.g. antikidnapping) and restitution. As such they do not have a primary orientation towards the criminal justice system and its underpinning philosophies, as is the case with public police.

- Policing by the private sector tends to be much more hardware/technology-intensive and less labourintensive than policing by the public police.

- Much private policing is "embedded" in other functions and occupations, rather than delivered by dedicated policing specialists. For example, company employees whose main responsibilities are not related to policing (e.g. sales clerks in retail stores) may be given some policing responsibilities (for an example at Disney World in Florida, see Shearing \& Stenning, 1984).

\section{The cost-benefit of private policing}

A number of explanations for the huge growth in private policing in recent decades have been suggested in the scholarly literature. Three of the key ones have been:

1. Private policing emerged to fill the gaps in demand for policing services that, in times of economic recession and fiscal restraint, could not be adequately met through public provision

2. Private policing emerged as a result of changes in the nature of property ownership (especially in urban centres) - in particular, the development of areas of "mass private property" such as large shopping malls, sports complexes and recreation centres, that are privately owned but designed for use by the

2. See: http://www.g4s.com/en/Media\%20Centre/News/2013/06/24/UK\%20Policing\%20Support\%20Services/ 
public generally. As well as other types of privately or "communally" owned property such as gated communities and condominium estates. Private owners of such properties have preferred private policing provision to public policing provision because (a) it is less expensive and more costeffective, and (b) they have greater control over it to ensure that it reflects their private or "communal" interests (see Kempa et al., 2004).

3. The kind of "contracting out" of government services and "responsibilisation" that neo-liberal governance and the "New Public Management" agenda encourages has favoured the growth of the private policing sector for philosophical reasons. As such, governments, as well as those to whom public policing responsibilities have been "devolved" in recent years, are major clients of the contract security industry.

Despite the circumstances that gave rise to the somewhat inevitable expansion of private policing provision, there are benefits to this pluralisation approach too. These include:

- Increased cost-effectiveness and efficiency; private security organisations hire and train specialists, unlike the public police whose employees all join initially as generalists (constables).

- Wider participation in the formulation of policing policy and determination of policing practices and priorities.

- Policing priorities and approaches can be more easily tailored to meet local and special policing needs and conditions, which means market efficiency.

- Increased opportunities to experiment with innovative approaches to doing policing due to a nimble and client-orientated business model, which may lead to increased effectiveness.

- Financial costs of policing are more likely to be borne by those who most benefit from it.

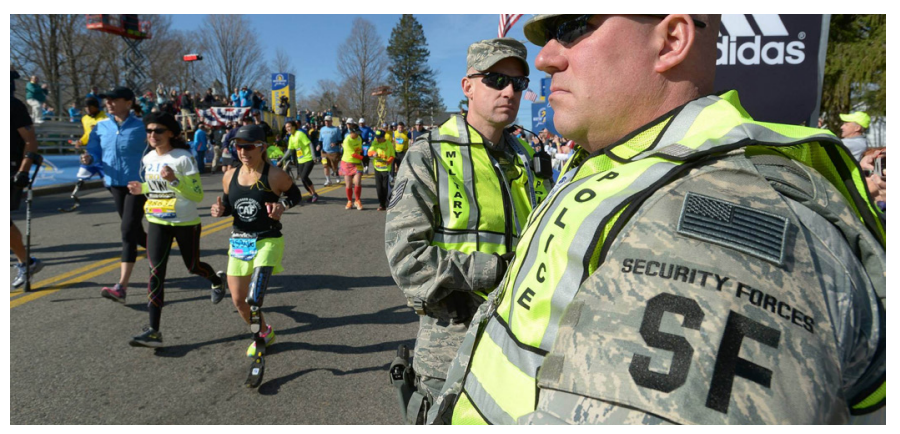

Of course, along with benefits there are also challenges posed by pluralisation that need to be considered. Many of these are counterpoints to the benefits listed above, and include:

- Inequitable access to effective policing because those who can afford to pay for private provision get better policing than those who cannot.

- Risk that the broader "public interest" in security, safety, justice, and respect for the law is too easily and frequently subordinated to narrow private interests such as profit and privilege.

- Difficulty in effectively regulating the private industry to ensure that minimum standards of policing and quality of provision are met by all providers; and that civil and human rights are observed and protected.

- Risk of exploitation by "unscrupulous" or corrupt private providers, e.g. failure to deliver advertised services, infiltration by criminal elements, etc.

- Risk of domestic (national) values being subverted by foreign-controlled private policing provision, which may be beyond effective domestic regulation. (See e.g. Thumala et al., 2011 for a discussion of some of these concerns)

\section{...established approaches to the governance and accountability of policing, [..] have until now been based on a very limited, conventional, understanding of policing}

Pluralisation and diversification of policing provision in terms of both the increasing diversity of state and nonstate providers, and the diversity of local, national and international environments in which these providers operate, therefore poses huge challenges for effective governance and accountability.

Our established approaches to the governance and accountability of policing, and the institutions we have established to accomplish it, have until now been based on a very limited, conventional, understanding of policing as the activities of locally or nationally based 'public police'.

Thinking about what new governance institutions will be needed for a plural policing environment is still in its infancy (see Johnston \& Shearing, 2003; Stenning, 2009; Johnston \& Stenning, 2010). Suggestions have included replacing police governing authorities with Policing Boards with a remit to govern and co-ordinate private as well as public policing provision (e.g. by the Patten Inquiry's report in Northern Ireland - Independent Commission, 1999).

Despite these, experimentation with such new institutions has barely begun. What is needed moving forward is a better appreciation, by politicians, media and the public, of the benefits of, and not just concerns about, plural policing provision, increased and betterinformed public discussion about it, and development 
of policy options which facilitate the realisation of these benefits, rather than just trying to constrain it.

\section{ON THE HORIZON}

We have noted that policing has "gone global" both literally as a response to policing challenges presented by globalisation and internationalisation; and figuratively with multiple representatives operating in policing within the state. Policing provision is pluralised at every level, and there remain ever new frontiers to this pluralisation.

\section{...cyberpolicing will present some of the biggest policing challenges in the immediately foreseeable future}

Technological developments have created a new spatial environment, for example - a virtual space or 'cyberspace'. Policing provision is also required here too. The online environment has generated new policing challenges through crime, including cybercrime, computer security, identity theft, internet pornography, and computer hacking to name a few. These are not territorially based and thus accountability and coordination become all the more difficult.

Not surprisingly, it is non-state policing providers who tend to be at the cutting edge of 'cyberpolicing', since most public police organisations have neither the technical expertise nor the necessary training to do this kind of work. Moreover most of cyberspace is controlled by private corporations such as Google, Facebook, YouTube, Microsoft, Apple, and other Internet Service Providers (ISPs), who contract private provision to fulfil their needs.

There can be no doubt that cyberpolicing will present some of the biggest policing challenges in the immediately foreseeable future, and it will be interesting to watch how public and private providers cooperate to deal with this threat to public and private safety.

Other developments to include (to mention only a few): climate change and the associated natural disasters and human migrations; new, and more expansive, understandings of 'human security', including food and water security, bio-security and control of the spread of infectious diseases; international terrorism; and transnational organised crime.

All of these developments pose both policing challenges and opportunities for more effective policing through pluralized policing provision. What is the appropriate blend of responsibility allocation for these in a pluralized policing environment?
Facing these challenges and taking fullest advantages of the opportunities that a pluralized approach can offer is going to be at the top of the agendas of police leaders in the coming decades. To do this requires a different way of viewing the responsibilities of public policing, and a different way of viewing the services that can be offered by private providers. Ensuring that the best of private provision can be blended with the best of public provision is essential in responding to what lies ahead (Ayling et al., 2009).

\section{REFERENCES}

Ayling, J., Grabosky, P., \& Shearing, C. (2009). Lengthening the arm of the law: Enhancing police resources in the 21st century. Cambridge: Cambridge University Press.

Bayley, D., \& Shearing, C. (1996). The future of policing. Law and Society Review 30(3), 585-606.

Bowling, B., \& Sheptycki. J. (2012). Global policing. Los Angeles/London: Sage Publications.

Brodeur, J-P. (2010). The policing web. Oxford: Oxford University Press.

Coggan, C., \& Gabites, L. (2007). Safety and local government - partnerships and collaboration: How to find all those intersections and actually do something about it. Social Policy Journal of New Zealand, 32, 94-105.

Crawford, A. (2006). Fixing broken promises? Neighbourhood wardens and social capital. Urban Studies, 43(5-6): 957-976.

Crawford, A., Lister,S., Blackburn, S. \& Burnett, J. (2005). Plural policing: The mixed economy of visible patrols in England and Wales. Bristol: Policy Press.

Hofstra, B. (1995). A helpful eye: Dutch city wardens - prevention first. Criminal Justice Matters, 20(1), 12.

Hoogenboom, R. (1991). Grey policing: a theoretical framework. Policing and Society, 2(1), 17-30.

Independent Commission on Policing for Northern Ireland \& Patten, Chris. (1999). A new beginning: policing in Northern Ireland. Belfast: Northern Ireland Office.

Johnston, L., \& Shearing, C. (2003). Governing security: Explorations in policing and justice. London/New York: Routledge.

Johnston, L., \& Stenning, P. (2010). Challenges of governance and accountability for transnational private policing. In Lemieux, F. (ed.) International police co-operation: Emerging issues, theory and practice. (pp. 281-297). Collumpton, U.K.: Willan Publishing.

Jones, T., \& Newburn, T. (Eds.) (2006). Plural policing: A comparative perspective. London/New York: Routledge.

Jones, T., \& Newburn, T. (1998). Private security and public policing. Oxford/ New York: Oxford University Press.

Kempa, M., Stenning, P., \& Wood, J. (2004). Policing communal spaces: a reconfiguration of the mass private property hypothesis. British Journal of 
Criminology, 44(4), 562-581.

Law Commission of Canada. (2006). In search of security: The future of policing in Canada. Available from http://www.publicsafety.gc.ca/lbrr/archives/ cnmcs-pleng/cn000032946641-eng.pdf

Maitland, F. (1885). Justice and police. London: MacMillan.

Millie, M., \& Herrington, V. (2006). Applying reassurance policing: Is it "Business as Usual"? Policing \& Society, 16(2), 146-163.

Rigakos, G. (2002). The new parapolice: Risk Markets and commodified social control. Toronto: University of Toronto Press.

Scahill, J. (2011). Blackwater: The rise of the world's most powerful mercenary army. London: Profile Books Ltd.

Shearing, C. \& Stenning, P. (1984). From the panopticon to Disney World: The Development of discipline. In Doob, A. and Greenspan, E. (Eds.) Perspectives in Criminal Law, (pp.335-349). Aurora: Canada Law Book Co.

Shearing, C., \& Stenning, P. (1983). Private security: Implications for social control. Social Problems, 30(5), 493-506.

Stenning, P. (2009). Governance and accountability in a plural policing environment: The story so far. Policing: A Journal of Policy and Practice, 3(1), 22-33.

Stenning, P., \& Shearing, C. (2012). The shifting boundaries of policing: Globalisation and its possibilities. In Newburn T. \& J. Peay (Eds.) Policing: Politics, culture and control, (pp. 265-284). 0xford: Hart Publishing.

The Big Society: Power to the people. (2013, August 21). The Economist. Retrieved from http://www.economist.com/blogs/blighty/2013/08/big-society

Thumala, A., Goold, B., \& Loader, I. (2011). A tainted trade? Moral ambivalence and legitimation work in the private security industry. British Journal of Sociology, 62(2), 283-303.

Zedner, L. (2007). Pre-crime and post-criminology? Theoretical Criminology ,11(2), 261-281.

This article is based on a chapter co-authored by Philip Stenning and Clifford Shearing (2012). It has been further developed following a presentation by Philip Stenning at the Australian Institute of Police Management in November 2013; and a presentation by Clifford Shearing in November 2014.

\section{瘦 AIPM}

Collins Beach Road, Manly NSW PO Box 168, Manly NSW 1655

Ph: +61299344800 (24 hrs)

Fax: +61299344780

aipm.gov.au

ABN 17864931143

\section{About the Authors:}

Professor Clifford Shearing

PhD, M Arts, B Social Sciences (Honours)

Professor Clifford Shearing joined Griffith University's School of Criminology and Criminal Justice in 2014. He also holds appointments at the universities of Cape Town and Montreal. He was at the Centre of Criminology at the University of Toronto from the mid-1960s to early 2001 when he moved to the Australian National University as a foundational member of RegNet. He held the Chair of Criminology and the National Research Chair in Security and Justice at the University of Cape Town, where he directed its Centre of Criminology, from 2006 to 2014. His research focuses on developments in the governance of security, most recently "environmental security". In addition to his academic outputs, Clifford has made policy contributions to reshaping policing and security in Canada, Jamaica, Nothern Ireland and South Africa.

\section{Professor Philip Stenning}

SJD, M Arts, LLM, B Arts (Hons)

Before coming to Griffith University in 2011, Philip spent five years as Professor of Criminology at Keele University in the UK. Prior to that, he was Professor and Director of the Institute of Criminology at Victoria University of Wellington, New Zealand, from 2003-2005. He was at the Centre of Criminology at the University of Toronto, Canada, from 1968-2002, progressing from Research Assistant to Associate Professor. In addition to his academic work during these years, Philip has served as a consultant and adviser to a wide range of government departments and commissions of inquiry in a range of countries including Canada, New Zealand, Australia, South Africa, Venezuela and Brazil, as well as to the Council of Europe and the United Nations.

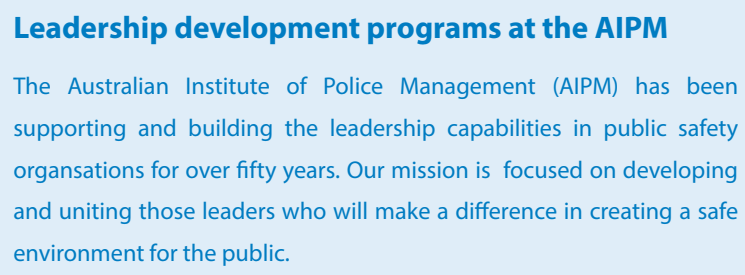

Nexus: Developing Strategic Partnerships (April 2015)

Developing Future Leaders (April/May 2015)

Custodian: Executive Management of Public Safety

Organisations (June 2015)

Evolve: Leadership in Complex Environments (June 2015)

Balance: Women Leaders in Public Safety (August 2015)

Bridging the Gap: from Management to Executive (November 2015)

Creative Common images:

https://www.flickr.com/photos/thenationalguard/13976946283; https://www.flickr.com/photos/ infomatique/5773366401; http://commons.wikimedia.org/wiki/File:Sydney_water_police1.JPG 